\title{
A New Combination in Senna (Leguminosae, Caesalpinioideae) from the Department of Valle del Cauca, Colombia
}

\author{
Philip A. Silverstone-Sopkin \\ Departamento de Biología, Universidad del Valle, A.A. 25360, Cali, Valle, Colombia \\ pasilverstone_sopkin@yahoo.com
}

Abstract. A new combination, Senna tocotana (Rose ex Britton \& Killip) Silverst., is proposed for Chamaefistula tocotana Rose ex Britton \& Killip, the latter name previously placed in synonymy of $S$. viminea (L.) H. S. Irwin \& Barneby. The Colombian species $S$. tocotana is not conspecific with the Jamaican species $S$. viminea. They differ notably in the size and shape of the fruits and in the arrangement of seeds; the fruits of $S$. viminea are shorter and broader than in $S$. tocotana, and the seeds are biseriate (in two rows) versus uniseriate in $S$. tocotana.

Resumen. Una nueva combinación, Senna tocotana (Rose ex Britton \& Killip) Silverst., se propone para Chamaefistula tocotana Rose ex Britton \& Killip, la cual estaba colocada en la sinonimia de $S$. viminea (L.) H. S. Irwin \& Barneby. La especie colombiana $S$. tocotana no pertenece a la misma especie como la especie jamaicana $S$. viminea. Ellas difieren notablemente en el tamaño y la forma de los frutos y en la ordenación de las semillas; los frutos de $S$. viminea son más cortos y más anchos que en $S$. tocotana, y las semillas son biseriadas (en dos filas), versus uniseriadas en S. tocotana.

Key words: Caesalpinioideae, Chamaefistula, Colombia, Leguminosae, Senna, Valle del Cauca.

The genus Senna Mill. (Leguminosae, Caesalpinioideae) includes 350 species, of which $80 \%$ are found in the New World (Marazzi et al., 2006). The New World species were revised by Irwin and Barneby (1982), who divided the genus into six sections and 35 series. The largest of the sections is Senna sect. Chamaefistula (DC. ex Collad.) H. S. Irwin \& Barneby. It is characterized by simple trichomes, ebracteolate pedicels, usually zygomorphic flowers, palmately veined sepals, and not more than seven fertile stamens, with the longest abaxial stamens parallel to the floral axis. Within the section Chamaefistula, the series Bacillares (Benth.) H. S. Irwin \& Barneby is characterized by a woody, caulescent, evergreen habit, leaves with two pairs of leaflets and one or two glands on the rachis, dimorphic fertile stamens with beaked anthers, and a turgid, often pulpy fruit, with at least 50 seeds arranged transversely to the longitudinal axis of the fruit. Marazzi et al. (2006) showed that, based on three chloroplast genes, the section Chamaefistula was paraphyletic, although the series Bacillares was supported as monophyletic.

In 1986, Jorge E. Ramos-Pérez and I began a floristic inventory of the few remaining small patches of secondary tropical dry forest in the Cauca Valley. One of these remnants is an island of 12.5 ha of forest surrounded by open fields of sugar cane at the Hacienda El Medio, near La Paila in the Municipio de Zarzal. This forest is the last vestige of a large cacao plantation that was abandoned in the 1930s. Here, we encountered an unidentified species of Senna (sect. Chamaefistula, ser. Bacillares), which seemed at first to be an undescribed taxon. Later, I examined specimens at COL and VALLE that were identified by E. P. Killip (probably in the 1940s) as Chamaefistula tocotana Rose ex Britton \& Killip; these specimens were collected between 1944 and 1946 by José Cuatrecasas-Arumí (J. Cuatrecasas $18393,19565,22019)$ from the eastern slope of the Cordillera Occidental of the Andes in the department of Valle del Cauca, Colombia, between 1680 and $2250 \mathrm{~m}$. The collections had been filed under $S$. viminea (L.) H. S. Irwin \& Barneby, following the synoptic treatment by Irwin and Barneby (1982), who placed $C$. tocotana in the synonymy of $S$. viminea without making the new combination in Senna.

The lectotype of Senna viminea (P. Browne s.n., LINN-528.6, collected in Jamaica) was designated by Fawcett and Rendle (1920: 102). I have seen images of the lectotype and five non-type specimens of $S$. viminea from Jamaica, and of the type collection of Chamaefistula tocotana (H. Pittier 720, holotype, US; isotype, NY), collected in Colombia. Data on labels of some of the specimens examined indicate that $S$. viminea is a vine, whereas $C$. tocotana is a shrub or small tree.

In the material examined, the fruits of the specimens of Senna viminea from Jamaica differ to such a degree from those of the type collection of 


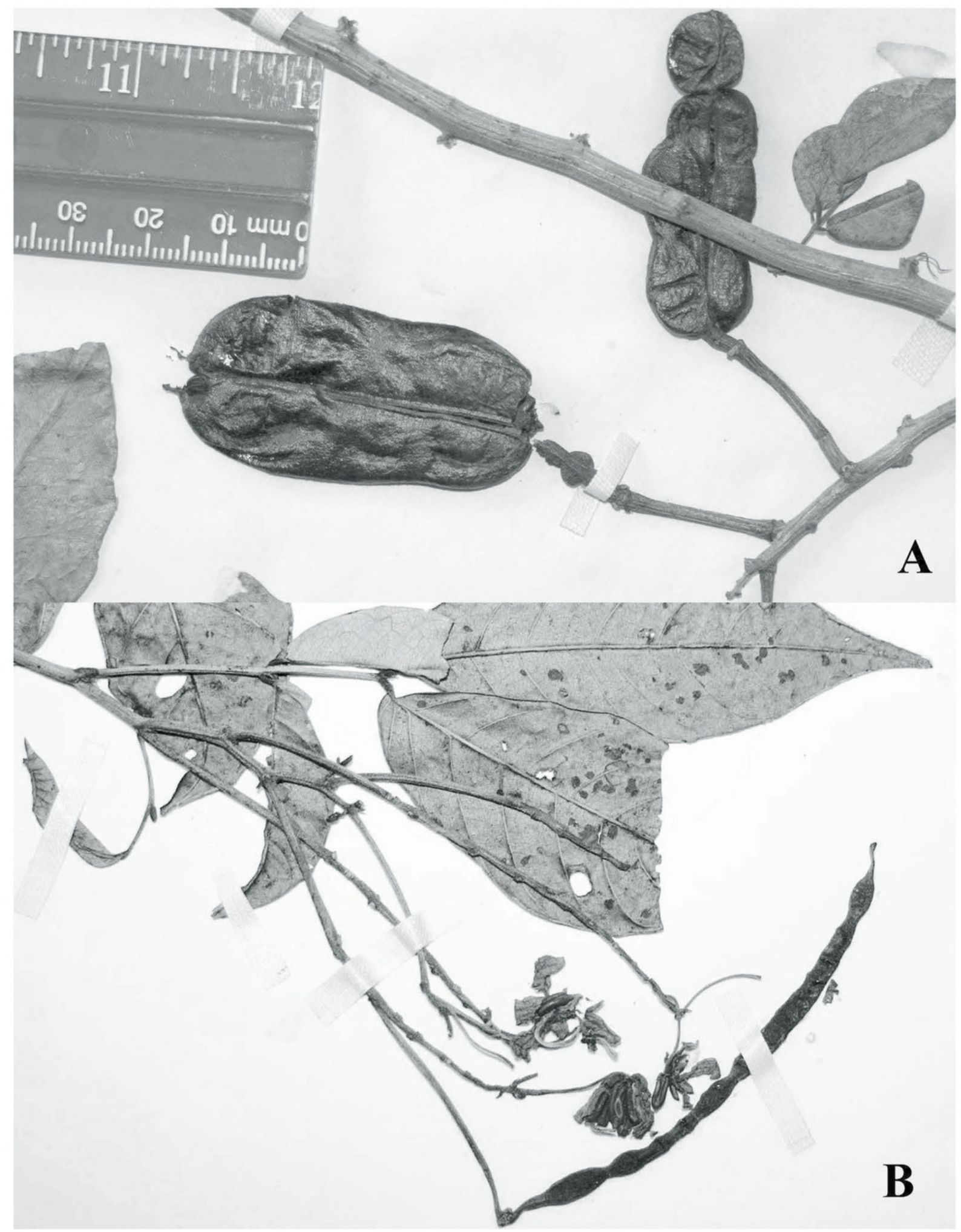

Figure 1. Comparison of fruits of two species of Senna. - A. S. viminea L. (N. L. Britton 2718, NY, not a type specimen). -B. Isotype specimen of S. tocotana (Rose ex Britton \& Killip) Silverst. (H. Pittier 720, NY).

Chamaefistula tocotana that they cannot belong to the same species (Fig. 1). The largest fruits of $S$. viminea are relatively short and broad. Measurements of eight fruits from four Jamaican specimens of $S$. viminea $(C$. L. G. Bertero s.n., MO; N. L. Britton 2718, NY; A. S. Hitchcock s.n., MO; J. W. Walker 297, US) are 1.9-
$5.3 \times 0.4-2.4 \mathrm{~cm}(1.5-4.8 \times$ longer than wide). In contrast, the largest fruit (immature) of the holotype (H. Pittier 720, US) of C. tocotana is elongate and narrow, $9.5 \times 0.5 \mathrm{~cm}(19 \times$ longer than wide).

Some Venezuelan specimens were provisionally determined by Irwin and Barneby (1982), following 
Bentham, as Senna viminea. I have seen images of one of these specimens (A. Fendler s.n., MO). Irwin and Barneby (1982) noted that these specimens lack fruits and thus cannot be definitively determined as $S$. viminea. The status of these Venezuelan specimens is uncertain, and I cannot include them in Chamaefistula tocotana.

The collections from Hacienda El Medio (Silverstone-Sopkin et al. 2547 and Silverstone-Sopkin \& Arroyo-Valencia 5442, Fig. 2) resemble the Cuatrecasas specimens of Chamaefistula tocotana in key diagnostic characters (leaflet number, size, and shape; sepal size, venation, and pubescence; seven subequal fertile anthers; fruit size and shape). Petal size for C. tocotana is similar: $12-12.5 \mathrm{~mm}$ in El Medio specimens and $12 \mathrm{~mm}$ in the protologue (Britton \& Killip, 1936). S. F. Smith (pers. comm.) measured the longest petal in the holotype of $C$. tocotana as $14 \mathrm{~mm}$, and the petals in the Cuatrecasas specimens at VALLE vary from 11 to $15 \mathrm{~mm}$ long; the difference in petal size between the El Medio and C. tocotana specimens is small and not consistent. The fruits of the El Medio specimens are similar to those of the type collection of $C$. tocotana in shape; their seeds are uniseriate (in one row), unlike the biseriate seeds of $S$. viminea as described by Irwin and Barneby (1982).

After examining the aforementioned specimens and images, I concluded that the unidentified species of Senna collected at the Hacienda El Medio is not a new species; it is conspecific with the type of Chamaefistula tocotana. Furthermore, C. tocotana is not conspecific with $S$. viminea. Therefore, I propose the following new combination.

Senna tocotana (Rose ex Britton \& Killip) Silverst., comb. nov. Basionym: Chamaefistula tocotana Rose ex Britton \& Killip, Ann. New York Acad. Sci. 35: 174. 1936. TYPE: Colombia. Valle del Cauca: Cuesta de Tocotá, rd. from Buenaventura to Cali, Dec. 1905, H. Pittier 720 (holotype, US; isotype, NY). Figures 1B, 2.

[This description is based on all specimens examined, except where otherwise noted.] Shrubs or small trees, ca. 2-4 m tall; young branches quadrangular, glabrous. Leaves with stipules filiform, $13 \mathrm{~mm}$ (in El Medio specimens), caducous; petioles $1.3-5.4 \mathrm{~cm}$, glabrous; rachises $1-4.9 \mathrm{~cm}$, glabrous, gland 1, on adaxial surface of rachis between proximal pair of leaflets, black, sessile, erect, conical, $3.5 \mathrm{~mm}$ long, terminal appendage of rachis very slender and inconspicuous, $1 \mathrm{~mm}$ long; leaflets in 2 pairs, petiolules $2 \mathrm{~mm}$, with black spiculiform trichomes at adaxial base; blades of distal pair of leaflets larger than those of proximal pair, 6.8-17.5 $\times$ 2.7-7.4 cm, usually elliptical, sometimes ovate or lanceolate, apex acuminate, base rounded to obtuse and unequal, major lateral veins in 9 to 14 pairs; blades of proximal pair of leaflets 2.9-11.1 × 1.6-5.9 $\mathrm{cm}$, ovate, apex acuminate, base rounded to obtuse and unequal, major lateral veins in 7 to 11 (to 14) pairs; both pairs of leaflets with margin revolute, almost glabrous except for a few small appressed trichomes on major veins of both surfaces or only below, border usually ciliolate. Inflorescence an axillary raceme, sometimes crowded at tip of branch in axils of very young leaves with glands and stipules but without leaflets, thus sometimes appearing paniculate, not surpassing mature leaves; peduncle $1.2-7.2 \mathrm{~cm}$, rachis $0.4-8 \mathrm{~cm}$, both puberulent, with whitish trichomes; bracts $2.5-4 \mathrm{~mm}$, concave on adaxial surface, lanceolate, apiculate, glabrescent except at base, margin ciliolate except at base. Flowers 4 to 35 per raceme; pedicels 4-22 $\mathrm{mm}$, puberulent; sepals $3-5 \times 1.4-3 \mathrm{~mm}$, only slightly unequal (but 1 sepal of each flower adaxially concave in El Medio specimens), ovate to elliptical, apex rounded, puberulent on both surfaces, with whitish trichomes, veins not prominent, green when fresh, light brown when dried; petals (dried specimens) 11$15 \times 4.5-7 \mathrm{~mm}$, (in alcohol, El Medio specimens) 12 $\times 6-7 \mathrm{~mm}$, subequal, elliptical to obovate, apex rounded, pubescent on both surfaces, bright yellow when fresh; adaxial staminodes $3,1-1.2 \mathrm{~mm}$, fertile stamens 7 , usually only slightly dimorphic, median stamens 4 , with filaments $2 \mathrm{~mm}$, puberulent, anthers (including beak $0.5 \mathrm{~mm}$ ) $5.2 \times 1.5 \mathrm{~mm}$, glabrous, abaxial stamens 3 , subequal, filaments $3.5 \mathrm{~mm}$, anthers (including beak $1.5 \mathrm{~mm}$ ) $4.8-5 \times 1.5 \mathrm{~mm}$, beaks curved and slightly bifid at tip, opening by 2 distal pores; pistil curved, $15 \mathrm{~mm}$ long when straightened (of which distal $4 \mathrm{~mm}$ is style), densely puberulent; ovules 83, 1 ovary counted (stamen and pistil measurements from El Medio specimens only, in alcohol). Fruit (not mature, El Medio specimens) 19.5-26 × 0.6-0.8 cm, cylindrical, lacking raised borders adjacent to sutures, slightly compressed between seeds, flexible, beaked (beak $4 \mathrm{~mm}$ ), sparsely puberulent (mostly on sutures), not papillate, shiny green when fresh, dehiscence unknown (perhaps indehiscent); seeds uniseriate, broadside to septa, embedded in thin pulp.

Distribution and habitat. Senna tocotana is known only from Colombia. It has been collected between 950 and $2250 \mathrm{~m}$, in cloud forest on the western and eastern slopes of the Cordillera Occidental and the western slope of the Cordillera Central, and in dry forest in the Cauca Valley. It 




Figure 2. Senna tocotana (Rose ex Britton \& Killip) Silverst. —A. Branch with inflorescence and infructescence. —B. Flower. -C. Adaxial staminode. -D. Fertile abaxial stamen. —E. Fertile median stamen. —F. Fruit. —G. Fruit, cross section, showing that seeds are uniseriate. - H. Sepal, abaxial view, showing that sepals are puberulent with inconspicuous veins. Drawn from P. A. Silverstone-Sopkin \& J. E. Arroyo-Valencia 5442 (CUVC), with B-H from material preserved in $70 \%$ ethanol and $5 \%$ glycerin. 
should be noted that the forest in the western part of the Hacienda El Medio, although designated as tropical dry forest (based on climate) according to the Holdridge system (1967), has a flora similar to that of tropical moist forest in Panama, with only $8 \%$ of the tree species deciduous, probably because of a high water table (the Río La Paila is only $120 \mathrm{~m}$ from the forest, which formerly was subject to seasonal flooding).

The type locality of Chamaefistula tocotana, Tocotá, is a village in the municipality of Dagua, department of Valle del Cauca, $22 \mathrm{~km}$ by road southeast of Dagua, on the old road from Cali to Buenaventura, at $1500 \mathrm{~m}$ elevation, on the western slope of the Cordillera Occidental of the Andes, at $3^{\circ} 31^{\prime} \mathrm{N}, 76^{\circ} 39^{\prime} \mathrm{W}$, below the pass of Las Cruces (IGAC, 1980; Paynter, 1997). Since the locality on the label of the holotype is "Cuesta [= slope, hill] de Tocotá,...1500-1900 m," the type may have been collected on the slope above the village of Tocotá.

Additional specimens examined. COLOMBIA. Valle del Cauca: Mpio. La Cumbre, vereda Chicoral, Cordillera Occidental, Res. Alto Bitaco, T. Cano 39 (CUVC); [Mpio. Cali], Cordillera Occidental, vertiente oriental, hoya del río Cali, vertiente derecha, Quebradahonda, arriba de La Glorieta, camino a Miralindo, J. Cuatrecasas 18393 (COL, VALLE); [Mpio. La Cumbre], Cordillera Occidental, La Cumbre, J. Cuatrecasas 19565 (VALLE); [Mpio. Cali], Cordillera Occidental, vertiente oriental, hoya del río Cali, río Pichindé, en Los Cárpatos, J. Cuatrecasas 22019 (COL, VALLE); Mpio. Yotoco, correg. Jiguales, vereda Jardín, finca Milán, W. Devia 897 (COL); hoya del río Cali, El Saladito, J. M. Duque-Jaramillo 1677 (VALLE); Mpio. Palmira, Cordillera Central, vertiente occidental, cuenca superior del río Nima, margen izquierda de quebrada Los Añascos, cerca a Tenjo, A. Roa 137 (CUVC); Mpio. Zarzal, Hacienda El Medio, valle geográfico del río Cauca, al W de carr. Panamericana, entre La Paila y Zarzal, $4^{\circ} 20^{\prime} 07^{\prime \prime} \mathrm{N}$, $76^{\circ} 04^{\prime} 52^{\prime \prime} \mathrm{W}$, P. A. Silverstone-Sopkin, N. Paz \& R. T. González 2547 (CUVC, NY), P. A. Silverstone-Sopkin \& J. E. Arroyo-Valencia 5442 (COL, CUVC, HUA, NY).

Acknowledgments. I am grateful to the late Rupert C. Barneby (NY) for his aid and advice; to James Luteyn and Patricia Holmgren (NY) for financial aid and for granting permission to visit the herbarium of the New York Botanical Garden in
1990, 1992, and 1993; to the Linnean Society of London, Gina Douglas, and Lynda Brooks (LINN) for sending an image of the lectotype of Cassia viminea; and to Stephen F. Smith (US), Douglas Daly, Michael Nee (NY), and Ana Isabel Vásquez-Vélez (CUVC) for providing measurements and photographs of Senna tocotana and S. viminea. I thank Luis E. Forero-Pinto (VALLE), Luis C. Jiménez-Bulla (COL), and Carlos Parra (COL) for permission to study specimens in their herbaria; and Esteban Uribe-Uribe (owner of the Hacienda El Medio), Alfonso Herrera, Jairo Jaramillo, and Carlos Ávila (administrators) for permission to collect at the Hacienda El Medio. I also thank my colleague Jorge E. Ramos-Pérez; our field assistants Jesús E. Arroyo-Valencia, Robert T. González, and Néstor Paz; the botanical illustrator Silverio GarzónGaviria for preparing Figure 2; and Gwilym Lewis (K) and Jorge Contreras (COL). Fieldwork in the Cauca Valley was financed by COLCIENCIAS grant \#110605-014-87 to the Universidad del Valle, "Flora Relictual del Valle Geográfico del río Cauca,” Jorge E. Ramos-Pérez, principal investigator.

\section{Literature Cited}

Britton, N. L. \& E. P. Killip. 1936. Mimosaceae and Caesalpiniaceae of Colombia. Ann. New York Acad. Sci. 35: 101-208.

Fawcett, W. \& A. B. Rendle. 1920. Flora of Jamaica, Containing Descriptions of the Flowering Plants Known from the Island, Vol. IV (Dicotyledons, Families Leguminosae to Callitrichaceae). British Museum of Natural History, London.

Holdridge, L. R. 1967. Life Zone Ecology, rev. ed. Tropical Science Center, San José, Costa Rica.

IGAC (Instituto Geográfico Agustín Codazzi). 1980. Diccionario Geográfico de Colombia, Vols. 1 \& 2. Bogotá.

Irwin, H. S. \& R. C. Barneby. 1982. The American Cassiinae, a synoptical revision of Leguminosae tribe Cassieae subtribe Cassiinae in the New World. Mem. New York Bot. Gard. 35: 1-918.

Marazzi, B., P. K. Endress, L. P. D. Queiroz \& E. Conti. 2006. Phylogenetic relationships within Senna (Leguminosae, Cassiinae) based on three chloroplast DNA regions: Patterns in the evolution of floral symmetry and extrafloral nectaries. Amer. J. Bot. 93: 288-303.

Paynter, R. A., Jr. 1997. Ornithological Gazetteer of Colombia, 2nd ed. Harvard University, Cambridge. 


\section{$2 \mathrm{BHL}$ Biodiversity Heritage Library}

Silverstone-Sopkin, Philip Arthur. 2012. "A New Combination in Senna (Leguminosae, Caesalpinioideae) from the Department of Valle del Cauca, Colombia." Novon a journal of botanical nomenclature from the Missouri Botanical Garden 22(1), 91-95. https://doi.org/10.3417/2007117.

View This Item Online: https://www.biodiversitylibrary.org/item/196082

DOI: https://doi.org/10.3417/2007117

Permalink: https://www.biodiversitylibrary.org/partpdf/218541

\section{Holding Institution}

Missouri Botanical Garden, Peter H. Raven Library

\section{Sponsored by}

Missouri Botanical Garden

\section{Copyright \& Reuse}

Copyright Status: Permission to digitize granted by rights holder Rights: https://www.biodiversitylibrary.org/permissions

This document was created from content at the Biodiversity Heritage Library, the world's largest open access digital library for biodiversity literature and archives. Visit BHL at https://www.biodiversitylibrary.org. 